\title{
Hyeres Seamount - a new insight into the Southern Azores Seamount Chain and the Azores Region
}

\author{
L.P. RIBEIRO ${ }^{1,2^{*}}$, P. MADUREIRA ${ }^{1}$, J. MATA $^{3}$
}

${ }^{1}$ Task Group for the Extension of the Continental Shelf (EMEPC) Rua Costa Pinto 165, 2770-047 Paço de Arcos, Portugal (* luisa.pribeiro@emepc.mm.gov.pt)

${ }^{2}$ GeoBioTec, Univ. Aveiro, Portugal

${ }^{3}$ Instituto Dom Luiz, FCUL, Univ. Lisboa, Portugal

The Southern Azores Seamount Chain (SASC) is rooted on a large terrace and encompasses the Plato $\left(33.2^{\circ} \mathrm{N}\right)$, Hyeres $\left(31.5^{\circ} \mathrm{N}\right)$, Small Hyeres $\left(30.9^{\circ} \mathrm{N}\right)$ and the Great Meteor $\left(29.8^{\circ} \mathrm{N}\right)$ seamounts. Based on geochemical and geophysical arguments, the SASC has been genetically linked to the Azores Archipelago $\left(36.9-39.7^{\circ} \mathrm{N}\right)$ and considered the first manifestation of the long-lived Azores mantle anomaly $[1,2]$, which large-scale interaction with the Mid-Atlantic Ridge is depicted on- and off-axis between Hayes and Maxwell fracture zones. Here we present the first elemental and isotopic data ( $\mathrm{Sr}-\mathrm{Nd}-\mathrm{Pb}-\mathrm{Hf})$ on basalts dredged on two sites at Hyeres Seamount $(-2500$ and $-1800 \mathrm{~m})$, during the EMEPC \Açores $\backslash$ G3 $\backslash 2007$ preparatory cruise for the Portuguese Extension of the Continental Shelf Submission. Only the least altered (LOI $<5$ wt.\%) samples were selected for this study.

Hyeres lavas are ultrabasic alkaline and display high $\mathrm{Nb} / \mathrm{Yb}$ and $\mathrm{Th} / \mathrm{Yb}$ ratios ( $\overline{\mathrm{x}}=43.4$ and 3.2, respectively) when compared with lavas from other SASC seamounts and even from the Azores (with $\bar{x}=28.4$ and 1.8 respectively). Lavas from Hyeres have primitive compositions as depicted by their high Ni (276-315ppm) contents and Mg\# (65-68) values. As indicated by their high $\mathrm{Nb} / \mathrm{Yb}$ ratios, they are generally characterized by strong enrichment in the most incompatible elements and strong REE fractionation $([\mathrm{La} / \mathrm{Yb}] \mathrm{n}=17.9-$ 22.0). Sr-Nd-Hf isotope ratios $\left({ }^{87} \mathrm{Sr} /{ }^{86} \mathrm{~S} \approx 0.70317\right.$; $\varepsilon N d \approx 6.5$ and $\varepsilon \mathrm{Hf} \approx 9.9$ ) are within the range found in the neighboring seamounts and the Azores, while $\mathrm{Pb}$ isotope ratios of some lavas from Hyeres can be slightly lower than the regional isotopic signature (Azores and SASC). The general isotopic similarity with the Azores and the SASC, but the more significant enrichment in the incompatible elements calls for lower degree of partial melting at Hyeres, in the presence of higher amounts of residual garnet (higher $\mathrm{Nb} / \mathrm{Yb}$ and $\mathrm{La} / \mathrm{Yb}$ ratios).

[1] Gente et al. (2003) G3 4, [2] Ribeiro et al. (2017) Lithos 294-295 